\title{
DETERMINANTS OF DISCLOSURE OF SUSTAINABILITY REPORTS IN LQ 45 COMPANIES LISTED ON IDX 2014 - 2018
}

\author{
Meiliyah Ariani* \\ Faculty of Business and Economy \\ Universitas Prof. Dr. Moestopo (Beragama) \\ Zulhawati \\ Faculty of Business and Humanities \\ Universitas Teknologi Yogyakarta \\ Hermiyetti \\ Faculty of Business and Economy \\ Universitas Bakrie \\ *Correspondence: meiliyahariannie@yahoo.co.uk
}

\section{ARTICLE INFO}

\section{Article History:}

received: $27 / 08 / 2021$

revised: $20 / 09 / 2021$

accepted: $31 / 10 / 2021$

\section{Keywords:}

Net Profit Margin, Debt Ratio, Dividend

Policy, and Sustainability Reporting

DOI:

https://doi.org/10.32509/mirshus.v1i2.17

\section{ABSTRACT}

This study aims to determine and analyze net profit margin, debt ratio, and dividend policy on Sustainability Reporting disclosure. The research sample used was 13 companies with the period 2014-2018. The sampling technique used purposive sampling technique. The data used in this study is using secondary data. The method used is a multiple regression technique that tests the variables of the panel data using SPSS 25. The results of this study indicate that net profit margin has a significant positive effect on Sustainability Reporting disclosure. With the increase in NPM (net profit margin), it will increase investor confidence in the company, so that the company's demands for its efforts in environmental and social performance are also higher. Debt ratio has a significant positive effect on Sustainability Reporting disclosure. The increase in the debt ratio shows the company's high need for fresh funds, the high value of the debt ratio also reveals the company's dependence on debt which can create risks for the company's survival. Dividend policy has a significant positive effect on Sustainability Reporting disclosure. The higher the level of dividend payments of a company, the level of disclosure in the Sustainability Report is also high. 


\section{INTRODUCTION}

The faster the times, the more human needs today. Business people are increasingly aggressively expanding to be able to reach all aspects of community needs. But on the other hand, the development of the company's operational activities coupled with the continuous exploitation of resources can result in environmental damage to social and economic conflicts if the surrounding community is not developed. Therefore, companies are required to take part in reducing these risks.

Corporate social responsibility (CSR) which is often discussed is corporate social responsibility (CSR). However, over time, environmental problems are not only related to CSR, but also issues that are currently developing, namely sustainable development. Since the 1980s, the idea of a sustainable living format has developed as a manifestation of collective awareness of the limitations of natural resources and the environment to support human life in the future. In 1989, the World Commission on Environment and Development (WCED)

In the 2000-2015 period, only 34 companies disclosed sustainability reports (Siska Liana, 2019). Therefore, it is hoped that with the development of the business world today, more companies will disclose sustainability reports to support the achievement of the SDGs (Sustainable Development Goals) in 2030.

This is in line with the Triple Bottom Line concept, namely that companies can grow sustainably in addition to increasing company income (profit), must care about people both employees and communities outside the company. The company is also responsible for protecting the environment or the earth (Maulida and Adam, 2012).

In Indonesia, the practice of disclosing environmental responsibility is also regulated in PSAK No. 1 Paragraph 14 (2013 revision) which implicitly recommends companies to disclose published the Brundtland Report in the Our Common Future document on sustainable development which was subsequently recognized and widely accepted as the basis for regulating a more sustainable world order. Sustainability is defined as "meeting the needs of the present without compromising meeting the needs of future generations". The goals of sustainable development or the so-called sustainable development goals are to end poverty, reduce inequality and protect the environment.

The SDGs (Sustainable Development Goals) have been established since August 2015 which are expected to be achieved by 2030. The SDGs (Sustainable Development Goals) are a design to replace the MGDs (Millennium Development Goals) which were designed to take effect from 20002015. All of the goals contained in the MDGs (Millennium Development Goals) are considered successful but only obtain quantitative data, such as Indonesia experiencing a 5 percent reduction in poverty in 2013-2014.

environmental responsibility in environmental reports and value added reports (iaiglobal.or.id). This is reinforced by POJK Number 51/POJK.03/2017 concerning the Implementation of Sustainable Finance for Financial Service Institutions, Issuers, and Public Companies as contained in Article 10 paragraph (1).

One of the guidelines for companies in publishing sustainability reports is GRI (Global Reporting Initiative), an international independent organization that has been a pioneer in sustainability reporting since 1997. GRI (Global Reporting Initiative) helps businesses and governments to understand and communicate their impact on issues such as change climate, human rights, governance and social. Based in Amsterdam, the Netherlands, this organization has collaborated with more than 100 countries 
around the world. GRI (Global Reporting Initiative) provides sustainability reporting standards concerning economic, environmental and social issues.

The real commitment to support the company for sustainable financial practices is to always pay attention to sustainability factors as the main consideration in making decisions as stated in the spirit of Good Corporate Governance (GCG) as a pillar. A good business is not just profit-oriented. More than that, a good business is a business that pays attention to sustainability and is friendly to the world and people.

From the statement above, it should be used as a reference for large companies that have gone public to participate in competing in the disclosure of sustainability reports. Because large companies tend to be the subject of supervision because they exploit more resources so that environmental, economic, and social problems arise. However, the disclosure of sustainability reports in Indonesia is still voluntary and not all business entities or companies carry out this practice.

The purpose of this study is to determine and prove the effect of Net Profit Margin, Debt Ratio and Dividend Policy on the Disclosure of Sustainability Reports in LQ45 companies listed on the IDX.

\section{METHOD}

This study uses a causal relationship research design. The type of data used in this research is secondary data. Data were obtained from various sources, including the Indonesia Stock Exchange (www.idx.co.id), and the Company's Website. The data used is a combination of time series and cross section which is called panel data.
The population used as a sample in this study is LQ45 companies listed on the Indonesia Stock Exchange for the period 2014-2018. The sample used is the annual report and sustainability report of companies including LQ45 companies listed on the Indonesia Stock Exchange.

While the research sample uses the Purposive Sampling method, which is a sampling technique based on selected groups where the characteristics of the criteria used as samples in this study are: (1) LQ45 companies listed on the Indonesia Stock Exchange (IDX) for the 2014-2018 period; (2) LQ45 company which has official website; (3) LQ45 companies that publish annual reports for the period 2014-2018; (4) LQ45 companies that use the rupiah currency in their annual reports for the period 2014-2018; (5) LQ45 companies that publish sustainability reports for the period 2014-2018; (6) LQ45 companies that have complete information needed related to measurement indicators used as variables in this study.

The data collection method in this study was carried out with a documentation study, namely by collecting secondary data in the form of financial statement information through the annual report of LQ45 companies listed on the Indonesia Stock Exchange, namely www.idx.co.id for the 2014-2018 period. The type of data used in this study is the type of secondary data

\section{DISCUSSION}

\section{Descriptive Test}

The results of the descriptive test in this study are:

Table 1. Descriptive Statistic

\begin{tabular}{|l|c|c|c|c|c|}
\hline & $\mathrm{N}$ & Minimum & Maximum & Mean & Std. Deviation \\
\cline { 2 - 6 } & Statistic & Statistic & Statistic & Statistic & Statistic \\
\hline Net Profit Margin & 65 &, 007 &, 279 &, 1335 &, 07279 \\
\hline Debt Rasio & 65 &, 153 & 11,854 & 3,1223 & 3,20575 \\
\hline Dividen Policy & 65 &, 120 &, 750 &, 3457 &, 14280 \\
\hline
\end{tabular}




\begin{tabular}{|l|c|c|c|c|c|}
\hline $\begin{array}{l}\text { Disclosure Index } \\
\text { Sustainability Report }\end{array}$ & 65 &, 424 &, 939 &, 7082 &, 12245 \\
\hline Valid N (listwise) & 65 & & & & \\
\hline
\end{tabular}

Source: Data Processed by SPSS 25

From the table above, it shows that the number of data samples (N) used and analyzed in this study are financial information data in the form of annual reports and sustainability reports of LQ45 companies listed on the Indonesia Stock Exchange in 2014 to 2018 for 5 years as many as 65 data samples.policy has a minimum value of 0.120 which is owned by PT Aneka Tambang Tbk. in 2014 and a maximum value of 0.750 which is owned by PT Bukit Asam Tbk. in 2018 with an average value of 0.3457 and a standard deviation of 0.1428; (4) The Sustainability Report disclosure index has a minimum value of
0.424 which is owned by PT Jasa Marga Tbk. in 2018 and a maximum value of 0.939 which is owned by PT Bank Rakyat Indonesia (Persero) Tbk. in 2014 with an average value of 0.7082 and a standard deviation of 0.12245 .

\section{Classic Assumption Test Results}

In this study, the normality test used nonparametric statistical analysis, namely by looking at one sample KolomogorovSmirnov (K-S). The following are the results of normality testing in this study:

Table 2. Normality Test Result

One Sample Kolmogorov Smirnov Test

\begin{tabular}{|l|l|r|}
\hline \multicolumn{2}{|l|}{} & Unstandardized Residual \\
\hline N & 65 \\
\hline \multirow{2}{*}{ Normal Parameters } & Mean &, 00000 \\
\cline { 2 - 3 } & Std. Deviation &, 08405 \\
\hline \multirow{3}{*}{ Most Extreme Differences } & Absolute &, 105 \\
\cline { 2 - 3 } & Positive &, 076 \\
\cline { 2 - 3 } & Negative & -105 \\
\hline Kolmogorov-Smirnov Z &, 105 \\
\hline Asymp. Sig. (2-tailed) &, 070 \\
\hline a. Test distribution is Normal. & \\
\hline \multicolumn{2}{|l|}{ b. Calculated from data. } \\
\hline
\end{tabular}

Source: Data Processed by SPSS 25

From the results of the normality test above, the Kolomogorov Smirnov value is 0.105 and the Asymp value. Significance (2tailed) at 0.070 with $=0.05$. This shows that the data is normally distributed.

\section{Autocorrelation Test}

The results of the autocorrelation test in this study are:

Table 3. Autocorrelation Test Results Model Summaryb

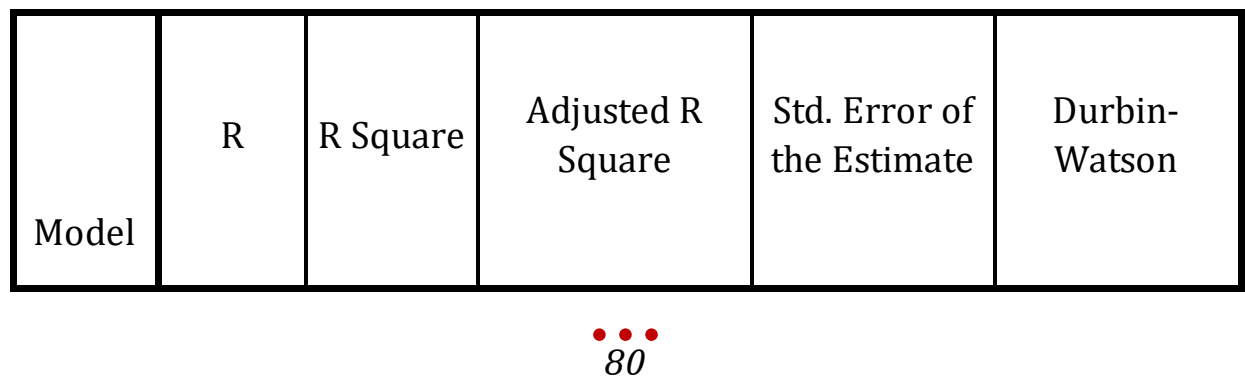




\begin{tabular}{|r|r|r|r|r|r|}
\hline 1 &, $727 \mathrm{a}$ &, 529 &, 506 &, 08609 & 1,721 \\
\hline
\end{tabular}

Source: Data Processed by SPSS 25

\section{Multicollinearity Test}

The multicollinearity test in this study can be seen from the results of the multicollinearity test in table 4, namely:

Table 4. Multicollinearity test Results Coeffecients ${ }^{\mathrm{a}}$

\begin{tabular}{|l|r|r|}
\hline \multirow{2}{*}{ Model } & \multicolumn{2}{|c|}{ Collinearity Statistics } \\
\cline { 2 - 3 } & Tolerance & \multicolumn{1}{|c|}{ VIF } \\
\hline (Constant) & & \\
Net Profit Margin &, 646 & 1,548 \\
Debt Ratio &, 627 & 1,595 \\
Dividen Policy &, 608 & 1,645 \\
\hline
\end{tabular}

Source: Data Processed by SPSS 25

Based on the results from the table above, it can be seen that the tolerance value generated for the Net Profit Margin (NPM) variable is 0.646, Debt Ratio (DER) 0.627 and Dividend Policy (DPR) 0.608. And each VIF value shows that variable Net Profit Margin (NPM) 1.548, Debt Ratio (DER) 1.595, and Dividend Policy (DPR) 1.645. It can be concluded that all independent variables in the regression model do not have multicollinearity and are suitable for use in this study.

\section{Heteroscedasticity Test}

The heteroscedasticity test in this study can be seen in table 5 as follows:

Table 5. Glejser Test Results Coefficientsa

\begin{tabular}{|c|c|c|c|c|c|}
\hline \multirow{2}{*}{ Model } & \multicolumn{2}{|c|}{$\begin{array}{l}\text { Unstandardized } \\
\text { Coefficients }\end{array}$} & \multirow{2}{*}{$\begin{array}{c}\begin{array}{c}\text { Standardized } \\
\text { Coefficients }\end{array} \\
\text { Beta }\end{array}$} & \multirow[b]{2}{*}{$t$} & \multirow[b]{2}{*}{ Sig. } \\
\hline & B & $\begin{array}{c}\text { Std. } \\
\text { Error }\end{array}$ & & & \\
\hline (Constant) & 081 & ,019 & & 3,971 &, 000 \\
\hline Net Profit Margin &,- 062 & ,105 &,- 093 &,- 592 &, 556 \\
\hline Debt Ratio &,- 001 & 002 &,- 098 &,- 612 &, 543 \\
\hline Dividen Policy & 000 & 055 & ,000 & ,002 & 998 \\
\hline
\end{tabular}

Source: Data Processed by SPSS 25

From the results of the Glejser test in the table above, it is known that the Net Profit Margin variable has a significance value of 0.556 , the Debt Ratio variable has a significance value of 0.543 , and the Dividend Policy variable has a significance value of 0.998. The three variables have a significance value of more than 0.05 , so it can be concluded that the variables of net profit margin, debt ratio, and dividend policy do not occur heteroscedasticity.

\section{Multiple Linear Regression Test results}

In the regression test which shows the effect and measures the strength between the three independent variables $(X)$ on the dependent variable (Y). It can be seen the results of SPSS data processing that produce output in the following table:

Table 6. Multiple Regression Test Results Coeffecientsa 


\begin{tabular}{|c|c|c|c|c|c|}
\hline \multirow{2}{*}{ Model } & \multicolumn{2}{|c|}{$\begin{array}{l}\text { Unstandardized } \\
\text { Coefficients }\end{array}$} & \multirow{2}{*}{$\begin{array}{c}\begin{array}{c}\text { Standardized } \\
\text { Coefficients }\end{array} \\
\text { Beta }\end{array}$} & \multirow[b]{2}{*}{$\mathrm{t}$} & \multirow[b]{2}{*}{ Sig. } \\
\hline & B & $\begin{array}{c}\text { Std. } \\
\text { Error }\end{array}$ & & & \\
\hline (Constant) & ,464 & ,036 & & 12,925 & ,000 \\
\hline 1 Net Profit Margin & ,706 & , 184 & ,420 & 3,837 & ,000 \\
\hline${ }^{1}$ Debt Ratio & ,013 & ,004 & ,341 & 3,075 & ,003 \\
\hline Dividen Policy & ,317 & 097 & ,369 & 3,278 & ,002 \\
\hline
\end{tabular}

Source: Data Processed by SPSS 25

\section{Hypothesis Test Results \\ F Test Results (Anova)}

The F statistical test in this study was carried out using a significance level of 0.05 and can be seen in the table below:

Table 7. F Test Results ANOVA ${ }^{a}$

\begin{tabular}{|ll|l|l|}
\hline \multicolumn{1}{|c|}{ Model } & F & Sig. \\
\hline 1 & $\begin{array}{l}\text { Regression } \\
\text { Residual } \\
\text { Total }\end{array}$ & 22,825 &, $000^{\mathrm{b}}$ \\
& & \\
\hline
\end{tabular}

Source: Data Processed by SPSS 25

Based on the table above, the $\mathrm{F}$ test value of 22.825 is greater than the $\mathrm{F}$ table 2.75 with a significance value of 0.000 which when compared to the alpha value of 0.05 $(5 \%)$ is smaller $(0.0000 .05)$ so it can be concluded that in this study the independent variables (net profit margin, debt ratio, and dividend policy) jointly affect the dependent variable (disclosure of the Sustainability Report).

\section{Statistical Test Results t}

The significance test of individual parameters $(\mathrm{t})$ in this study can be seen in table 8 below:

Table 8. T Test results Coeffcients ${ }^{\mathrm{a}}$

\begin{tabular}{|c|c|c|c|c|c|}
\hline \multirow{2}{*}{ Model } & \multicolumn{2}{|c|}{$\begin{array}{l}\text { Unstandardized } \\
\text { Coefficients }\end{array}$} & \multirow{2}{*}{$\begin{array}{c}\begin{array}{c}\text { Standardized } \\
\text { Coefficients }\end{array} \\
\text { Beta }\end{array}$} & \multirow[b]{2}{*}{$t$} & \multirow[b]{2}{*}{ Sig. } \\
\hline & B & $\begin{array}{c}\text { Std. } \\
\text { Error }\end{array}$ & & & \\
\hline (Constant) & ,464 & ,036 & & 12,925 & 000 \\
\hline Net Profit Margin & ,706 & ,184 & ,420 & 3,837 & ,000 \\
\hline 1 Debt Ratio & ,013 & ,004 & 341 & 3,075 & ,003 \\
\hline Dividen Policy & ,317 & ,097 & ,369 & 3,278 & ,002 \\
\hline
\end{tabular}

Source: Data Processed by SPSS 25

Hypothesis Test Results F Test Results (Anova)
The F statistical test in this study was carried out using a significance level of 0.05 and can be seen in the table below: 


\begin{tabular}{|ll|l|r|}
\hline \multicolumn{1}{|c|}{ Model } & $\mathrm{F}$ & Sig. \\
\hline 1 & $\begin{array}{l}\text { Regression } \\
\text { Residual } \\
\text { Total }\end{array}$ & 22,825 &, $000^{\mathrm{b}}$ \\
\hline
\end{tabular}

Source: Data Processed by SPSS 25

Based on the table above, the $\mathrm{F}$ test value of 22.825 is greater than the $F$ table 2.75 with a significance value of 0.000 which when compared to the alpha value of 0.05 $(5 \%)$ is smaller $(0.0000 .05)$ so it can be concluded that in this study the independent variables (net profit margin, debt ratio, and dividend policy) jointly affect the dependent variable (disclosure of the Sustainability Report).

\section{Statistical Test Results t}

The significance test of individual parameters $(\mathrm{t})$ in this study can be seen in table 8 below:

\begin{tabular}{|c|c|c|c|c|c|}
\hline \multirow{2}{*}{ Model } & \multicolumn{2}{|c|}{$\begin{array}{l}\text { Unstandardized } \\
\text { Coefficients }\end{array}$} & \multirow{2}{*}{$\begin{array}{c}\begin{array}{c}\text { Standardized } \\
\text { Coefficients }\end{array} \\
\text { Beta }\end{array}$} & \multirow[b]{2}{*}{$\mathrm{t}$} & \multirow[b]{2}{*}{ Sig. } \\
\hline & B & $\begin{array}{c}\text { Std. } \\
\text { Error }\end{array}$ & & & \\
\hline (Constant) & 4,464 & ,036 & & 12,925 & ,000 \\
\hline Net Profit Margin & ,706 & ,184 & ,420 & 3,837 & ,000 \\
\hline${ }^{1}$ Debt Ratio & 013 & ,004 & ,341 & 3,075 & ,003 \\
\hline Dividen Policy & ,317 & ,097 & ,369 & 3,278 & ,002 \\
\hline
\end{tabular}

Source: Data Processed by SPSS 25

\section{Model Feasibility Test}

The results of the coefficient of determination test $\left(R^{\wedge} 2\right)$ in this study can be seen in the table below:
Table 8. Coeffecient of Determination Test Results Model Summaryb

\begin{tabular}{|l|r|r|r|r|}
\hline Model & $\mathrm{R}$ & R Square & $\begin{array}{c}\text { Adjusted R } \\
\text { Square }\end{array}$ & Std. Error of the Estimate \\
\hline 1 &, $727 \mathrm{a}$ &, 529 &, 506 &, 08609 \\
\hline
\end{tabular}

Source: Data Processed by SPSS 25

From the table above, it is known that the value of Adjusted $R$ Square $\left(\mathrm{R}^{2}\right)$ is 0.506 or $51 \%$, this shows that the change in the dependent variable caused by the independent variable is $51 \%$, meaning that the net profit margin, debt ratio, and dividend policy on the disclosure of the sustainability report are by $51 \%$ while $49 \%$ is explained or influenced by other variables that are not used in this study.

\section{Discussion}

Effect of Net Profit Margin on Disclosure of Sustainability Reports 
The first hypothesis in this study states that the net profit margin (NPM) has a positive and significant effect on the disclosure of the Sustainability Report. The results of this study prove that the role of net profit margin or profit margin on the company's sales has the potential to reveal the company's performance in the Sustainability Report. With the increase in NPM (net profit margin), it will increase investor confidence in the company, so that the company's demands for its efforts in environmental and social performance are also higher. This makes the company will

In addition, the disclosure of sustainability performance can convince consumers that the products produced by the company do not have a negative impact on social and environmental aspects and can be accounted for, so as to increase sales due to increased consumer interest. Then the company's profit margin will increase further in the next period, which will also have an impact on a higher level of disclosure of sustainability performance. Therefore, one of the factors in the effort to disclose sustainability reports is the profit margin of a company, where in order to perform economic, social and environmental performance, the company needs some funds that come from the profit.

\section{The Effect of Debt Ratio on Sustainability Report Disclosure}

The second hypothesis in this study states that the debt ratio has a significant positive effect on the disclosure of the Sustainability Report. The results of this study prove that the role of the debt ratio in the practice of disclosure of the Sustainability Report.

The increase in the debt ratio shows the company's high need for fresh funds, besides the high value of the debt ratio also reveals the company's dependence on debt which can create risks for the company's survival. One of the efforts made by carry out and disclose the sustainability report voluntarily.

High profit margins will encourage managers to provide more detailed information, because they want to convince investors of the company's profit level and encourage compensation to management. Wider disclosure is intended to reduce conflict and suppress negative issues in the company. Thus, management shows that the profit is not only used for its own interests, but also for the benefit of investors through social and environmental disclosures made.

management to increase the value of the debt ratio is to fulfill funding policies for productive financial activities, to encourage trust and a high corporate image for stakeholders.

The increase in debt position will help the company's funding activities to carry out activities outside of operational activities, one of which is to encourage the improvement of the company's image through disclosure of sustainability report disclosures. Companies with high debt ratios seek to gain legitimacy from stakeholders (including investors and creditors) through sustainability reports. The higher the value of a company's debt ratio, the more and better sustainability reports will be disclosed. Disclosure of the Sustainability Report can maintain the support and trust of stakeholders. This is because sustainability reports can be used by companies to obtain loans or capital from stakeholders and also as a form of accountability for the capital provided by stakeholders.

With a high debt ratio, creditors will reconsider when the company settles the company's obligations or liabilities that are due. Therefore, with the disclosure of the Sustainability Report, it can help creditors determine risk factors related to the company's business practices so that the company can maintain credibility and achieve the existence of stakeholders. 


\section{The Effect of Dividend Policy on Disclosure of Sustainability Reports}

The third hypothesis in this study states that dividend policy as proxied by the dividend payout ratio has a positive and significant effect on the disclosure of the Sustainability Report. This proves that the higher the level of dividend payments of a company, the higher the level of disclosure in the Sustainability Report.

If dividends are distributed regularly, it will indicate that the company's responsibility to stakeholders is getting better. The amount of dividends distributed to shareholders will be an attraction for shareholders because dividends are more certain. With a high dividend payout ratio, it can be seen that the company has the power to pay dividends with a high rate of return. This is to show investors, creditors, and the public that the company remains in a healthy condition.

The value of DPR (Dividend Payout Ratio) is one of the indicators used by investors in assessing the performance of a company. The greater the value of the dividend payout ratio will attract investors to invest in the company. Then the company's management will also try to be more transparent about the company's performance. This is what encourages companies to make more disclosures in their

\section{REFERENCES}

Amran, A., and Say Keat Ooi. (2016). Business Strategy For Climate Change: An ASEAN Perspective. Corporate Social Responsibility and Environmental Management 23 (4), 213-227. Wiley Online Library.

Ariyani, Agnes Pravita dan Oct. Digdo Hartomo. (2018). Analysis of Key Factors Affecting The Reporting Disclosure Indexes of Sustainability Reporting In Indonesia. Indonesia International Journal of Business, sustainability reports. In addition, a company with a high DPR (Dividend Payout Ratio) indicates that the company has more funds to carry out more social activities so that more information can be disclosed in the Sustainability Report. This means that more items will be disclosed in the Sustainability Report.

\section{CONCLUSION}

This study aims to examine the effect of net profit margin, debt ratio, and dividend policy on the disclosure of the Sustainability Report. This analysis was carried out using descriptive statistics and multiple linear regression using SPSS 25 . The data collected was 65 samples consisting of 13 companies included in the LQ45 index listed on the Indonesia Stock Exchange for the 2014-2018 period. Based on the results of previous studies and discussions, the conclusions of this study are as follows; (1) Net profit margin (NPM) has a significant and positive effect on the disclosure of the Sustainability Report in LQ45 companies for the 20142018 period; (2) The debt ratio (DER) has a significant and positive effect on the disclosure of the Sustainability Report in LQ45 companies for the 2014-2018 period; (3) Dividend policy (DPR) has a significant but positive effect on the disclosure of the Sustainability Report in LQ45 companies for the 2014-2018 period

Economics and Law, Vol. 16, Issue 1 (August). Soegijapranata Catholic University. Semarang.

Brigham, Eugene F dan Houston. (2006).

Fundamental of Financial Management: Dasar-Dasar Manajemen Keuangan. Edisi 10. Jakarta: Salemba Empat.

Fadhila Adhipradana, D. (2014). Pengaruh Kinerja Keuangan, Ukuran Perusahaan, Dan Corporate Governance Terhadap Pengungkapan Sustainability Report. Universitas Diponegoro. Semarang.

Fitri, Annisa Annur dan Willy Sri Yuliandri. (2018). Pengaruh Kinerja Keuangan 
Terhadap

Pengungkapan

Sustainability Report. e-Proceeding of Management: Vol.5, No.2 Agustus 2018. Universitas Telkom.

and Finance: Vol. 5, Issue 2, 2019, 219-229. Universitas Mercu Buana. Jakarta.

Herawati dan Yossi Diantimala. (2016). Tingkat Pengungkapan Keberlanjutan (Sustainability Disclosure): Analisis Perbandingan Perusahaan Keuangan dan Perusahaan Non Keuangan Di Indonesia. Jurnal Telaah Dan Riset Akuntansi. Vol. 9 No. 2, Juli 2016, PP 127-142. Universitas Syiah Kuala.

Hery dan Widyawati. (2011). "Akuntansi Keuangan Menengah 2". Jakarta: Bumi Aksara

Harmono. 2011. Managemen Keuangan Berbasis Balanced Scorecard Pendekatan Teori, Kasus, dan Riset Bisnis. Edisi 1. Jakarta: Bumi Aksara.

Ikatan Akuntan Indonesia (IAI). (2013). Pernyataan Standar Akuntansi Keuangan (PSAK) No. 1: Penyajian Laporan Keuangan. Jakarta: IAI.

Maulida, Ken Auva dan Adam, Helmy. (2012). Faktor- Faktor Yang Mempengaruhi Pengungkapan

Liana, Siska. (2019) . Pengaruh Profitabilitas, Leverage, Ukuran Perusahaan, dan Dewan Komisaris Independen terhadap Pengungkapan Sustainability Report. Jurnal Ekonomi dan Ekonomi Syariah. Vol. 2 No. 2, Juni 2019. Universitas Padjadjaran Bandung.

Safitri, Mariya, dan Saifudin. (2019) . Implikasi Karakteristik Perusahaan dan Good Corporate Governance Terhadap Pengungkapan Sustainability Report. Jurnal Bingkai Ekonomi. JBE Vol. 4 , No. 1, Januari 2019, pp: 13 - 25. Universitas Semarang.

Sulistyawati, Ardiani Ika dan Aprilia Qadriatin. (2018). Pengungkapan Keberlanjutan Laporan Keberlanjutan dan Faktor-Faktor yang

Sartono, R. Agus. (2010). Manajemen Keuangan Teori dan Aplikasi. Edisi
Hidayah, Nurul, Ahmad Badawi, dan Lucky Nugroho. (2019). Factors Affecting The Disclosure Of Sustainability Reporting. International Journal of Commerce

Irawati, Susan. 2006. Manajemen Keuangan. Pustaka: Bandung.

Jusuf, Jopie. (2014). Analisis Kredit Untuk Kredit (Account) Officier. Cetakan kedua belas. Jakarta: PT Gramedia Pustaka Utama.

Juliandi, Azuar., dkk. (2016). Mengolah Data Penelitian Bisnis Dengan SPSS. Medan: Lembaga Penelitian Dan Penulisan Ilmiah AQLI.

Kiliç, Merve And Cemil Kuzey. 2018. Factors Influencing Sustainability Reporting: Evidence from Turkey. SSRN 3098812.

Kasmir. (2008). Analisis Laporan Keuangan. Jakarta: Raja Grafindo Persada.

Meutia, Farah dan Farida Titik. (2019). Pengaruh Profitabilitas, Leverage, Ukuran Perusahaan, dan Kepemilikan Publik Terhadap Pengungkapan Laporan Keberlanjutan. e-Proceeding Of Management: Vol. 6, Agustus 2019. Universitas Telkom.

Keberlanjut Performance. Jurnal Ilmiah Mahasiswa FEB. Universitas Brawijaya

Ruhana, Aswi., dan Nurul Hidayah. (2019). The Effect of Liquidity, Firm Size, and Corporate Governance Toward Sustainability Report Disclosures. Advances in Economics, Business and Management Research, volume 120. Universitas Mercu Buana.

Sinaga, Korentina Juniasti dan Fachrurrozie. (2017). The Effect of Profitability, Activity Analysis, Industrial Type and Good Corporate Governance Mechanism on The Disclosure of Sustainability Report. Accounting Analysis Journal. Universitas Negeri Semarang.

Mempengaruhinya. Majalah Ilmiah Solusi, Vol. 16, No.4, Oktober 2018, Universitas Semarang.

keempat. Yogyakarta: BPFEYogyakarta. 
Syamsuddin. (2011). Manajemen Keuangan. Jakarta: PT Grafindo Persada.

Yunita, Nur afni dan Nova Friskarunia. (2016). Pengaruh Kebijakan Hutang, Earning Per Share, Net Profit Margin, dan Profitabilitas Terhadap Dividend
Payout Ratio Pada Perusahaan yang Terdaftar Di LQ45 Periode 2010-2014. Jurnal Akuntansi Dan Keuangan. Volume 4, Nomor 1, Februari 2019 P.129-146. Universitas Malikussaleh. 